\title{
THE IMPACT OF TRANSFER OF CACAO COMMODITIES TO CORN ON FARMERS 'INCOME IN BANGSALA VILLAGE, POREHU SUB-DISTRICT NORTH KOLAKA DISTRICT
}

\author{
Werni Maripadang $^{\left.1^{*}\right)}$, Lukman Yunus ${ }^{1)}$, Rosmawaty ${ }^{1)}$ \\ ${ }^{1}$ Department of Agribusiness Faculty of Agriculture Universitas Halu Oleo Kendari 93232 \\ ${ }^{*}$ Corresponding author : wernimaripadang@gmail.com
}

To cite this article:

Maripadang, W., Yunus, L., \& Rosmawaty, R. (2021). The Impact of Transfer of Cacao Commodities to Corn on Farmers 'Income in Bangsala Village, Porehu Sub-District North Kolaka District. International Journal of Agricultural Social Economics and Rural Development (ljaserd), 1(1), 24 - 29. doi:http://dx.doi.org/10.37149/ijaserd.v1i1.14162

Received: September 20, 2020; Accepted: February 01, 2020; Published: February 11, 2021

\begin{abstract}
The purpose of this study was to determine the factors causing the transfer of commodity cocoa to maize in Bangsala Village, Porehu Sub District, North Kolaka District and the impact of commodity transfer of cocoa to corn on farmers' income. The research location was determined with the consideration that Bangsala Village had the largest number of farmer households that shifted commodities compared to other villages. The number of samples in this study was 49 people while the methods used in this study were descriptive analysis, income analysis, and t-test. The results showed that the factors that influenced the farmers to switch from cocoa commodities to corn were technical factors including hard cacao care, pests and diseases that were difficult to control, and the old age of the cocoa plants. Economic factors include low selling prices, lower production, and lowprofit rates. Social factors include seeing the success of friends, following friends, and their own beliefs. The impact of the conversion of cocoa commodities to corn is seen in the increased income of farmers, farmers have additional income from their cocoa plantations, namely corn plants. It is clear here that the conversion of cocoa plant commodities to corn has a positive impact on the community in Bangsala Village, Porehu Sub District, North Kolaka District. The sig (2-tailed) value is $0.000<0.05$, that is, there is a significant difference between the income of the respondent farmers on the cornfield and on the cocoa field, thus the commodity transfer affects the farmer's income.
\end{abstract}

Keywords: commodity transfer, cocoa farming; corn farming; North Kolaka District; Porehu SubDistrict

\section{INTRODUCTION}

Indonesia is a country with abundant natural resources, not only as a maritime country but also as an agricultural country where agriculture is one of the main bases supporting the national economy. The agricultural sector includes the food crops, plantation, horticulture, fishery, and forestry sub-sectors, all of which are the main bases that make a major contribution to national development such as increasing national food security, increasing public income, earning foreign exchange through import-export, absorption of labor, and an increase in Gross Domestic Product (GDP).

Agricultural businesses, farmers are always faced with various options along the processing process of their agricultural business. This choice can be in the form of selecting a suitable agricultural location, types of commodities to be cultivated, fertilizers and pests to be used, places for marketing the agricultural commodities, processing methods or strategies, and so on. There are so many choices that accompany farmers in their business, of course as a business actor will choose one of the several options and this process can be said to be a decision-making process. Recently, there have been various issues where farmers may feel dissatisfied or not getting profit from one agricultural commodity, they then switch, replace or exchange their agricultural commodities with other commodities on the same agricultural land and this activity the researcher calls commodity transfer (Nurmedika, et al., 2015).

Bangsala Village is one of the villages in Porehu Subdistrict, North Kolaka District, wherein Bangsala Village many farmer households have switched their plant functions from cacao to corn 
planting. The number of agricultural business households is $400 \mathrm{kk}$, the number of cocoa farmers is 150 families, and the corn farmers are 250 families. The number of farmers who switched functions from cocoa to corn farmers was $98 \mathrm{kk}$. The factor that makes the prospect of corn farming quite bright is the tropical climate in Indonesia which is very suitable for growing maize. Its cultivation, which is not too difficult, makes this farming business quite promising. In addition, the always high demand for corn, both for consumption and for the benefit of the processed food industry, has made the potential for corn farming to be even greater in generating profits (Syahrial, 2019).

Based on BPS data in 2019, the area of plantation crops for cocoa from 2015 to 2018 was the same or fixed area with an area of 16,009 ha and drastically decreased land use for cocoa plants with an area of 8,304 ha. Whereas for maize plants from 2015 to 2017 for maize, the area was 132 ha and in 2018 and 2019 had increased with the area being 298 and 409 ha, respectively. (BPS Kabupaten Kolaka Utara, 2019)

Many farmers speculate that they will switch from cocoa to corn because there is information that corn is more promising. The corn plant is also one of the staple food commodities that is needed today. Corn plays an important role in various levels of society. For example in the food industry, corn can be used as a substitute for rice by processing it into corn rice, grits, and various other culinary corns. The most important part of corn itself is a staple ingredient in the animal feed manufacturing industry. If you pay attention, no less than $50 \%$ of the composition of animal feed on the market uses basic ingredients made from corn. This is what makes the business of growing corn very profitable for farmers because corn has a high economic value in the eyes of the community, and this is a good sign for corn farmers in Bangsala Village because their yields will be sold in the market at high prices. The hope of farmers in Bangsala Village in converting cocoa commodities to corn, their income can increase and increase. So that the household needs of farmers can be fulfilled and can improve their economy. Based on the background description, the purpose of this study is to determine the factors causing the transfer of cocoa to maize in Bangsala Village, Porehu Sub District, North Kolaka District and the impact of commodity transfer of cocoa to corn on income. Farmer

\section{MATERIALS AND METHODS}

The research location was determined based on the balance that Bangsala Village had the largest number of farmer households who switched commodities compared to other villages. This research was conducted from January to February 2020. The types of data used were primary data and secondary data. Meanwhile, to determine the factors causing the transfer of cocoa to maize commodities in Bangsala Village, Porehu Sub District, North Kolaka District, descriptive data analysis and analysis were used to determine the impact of cocoa-to-corn commodity transfer on farmers' income using the systematic formula proposed by Soekartawi (2002) as follows:

$$
\mathrm{I}=\mathrm{TR}-\mathrm{TC}
$$

Where:

$\begin{aligned} \text { I } & =\text { Income) (IDR) } \\ \text { TR } & =\text { Total Revenue }(\mathrm{Kg}) \\ \text { TC } & =\text { Total Cost (IDR) }\end{aligned}$

Knowing the difference in farmer income between cocoa fields and cornfields using t-test analysis with the following equation:

Where:

$$
\begin{aligned}
t \text { hit }= & \frac{\overline{x_{1}}-\overline{x_{2}}}{\sqrt{\left(n_{1}-1\right) S_{1^{2}}+\left(n_{2}-1\right) S_{2^{2}}\left(\frac{1}{n_{1}}+\frac{1}{n_{2}}\right)}} \\
& s_{1}=\sqrt{\frac{\left(x_{1}-\overline{x_{1}}\right)}{n_{1}-1}} \quad S_{2}=\sqrt{\frac{\left(x_{2}-\overline{x_{2}}\right)}{n_{2}-1}}
\end{aligned}
$$

$\mathrm{t} \quad=$ see the difference in income earned

$X_{1}=$ average income of farmers in cocoa fields

$X_{2}=$ average income of farmers in cornfields

$n_{1}=$ number of samples of farmers who grow cocoa

$\mathrm{n}_{2}=$ number of samples of farmers who grow corn

$\mathrm{S}_{1}^{2}=$ standard deviation / variation of farmers' income on cocoa land

$\mathrm{S}_{2}{ }^{2}=$ standard deviation / variation of farmers' income in cornfields 


\section{RESULTS AND DISCUSSION}

\section{Respondent Characteristics}

Farmer's age greatly affects the ability to work and how to think so that it will directly affect the management of his farm. According to Soehardjo and Patong (1984), the age interval 15-55 years is categorized as the productive age group while at the age interval 55 years and over, it is categorized as the unproductive age group. Respondent farmers who switch cocoa to corn 15 to 55 years with a percentage of $93.11 \%$ are categorized as productive and are working-age population and a small proportion are above 55 years old with a percentage of $6.89 \%$ who are categorized as non-productive or non-working age.

Education is a matter that has enough influence on the types of activities carried out. The higher the education, the easier it will be for farmers to adopt new technologies that will affect their farming. In the end, this will also affect the fulfillment of food needs in the family (Nurmedika, et al., 2015). Most of the respondents have graduated from elementary school (SD), as many as 21 people $(44.89 \%)$. While the least respondents were not attending school, namely 3 people $(6.12 \%)$. Respondents who graduated from junior high school were 8 people $(14.28 \%)$ and respondents who graduated from senior high school (SLTA) were 12 people (26.53\%). And the respondents who arrived at college were 5 people (8.16\%).

The level of education taken by the respondents can affect their creativity as well as their absorption of information and more advanced farming technology. The low level of education of respondents will affect their ability to understand various things related to farming technology, especially the awareness and availability of farmers in accepting new innovations.

Business experience is the number of years of experience that smallholders have gone through as part of the learning process in cultivation, production, and business and marketing of crops in order to generate income. Respondent farmers who switch from cocoa to corn in Bangsala Village are predominantly experienced in running farming activities. This is supported by the results of research which shows that the farming experience category of all respondents is very experienced. This indicates that farmers' knowledge in farming is very good because the farming experience will motivate farmers to correct or evaluate themselves about their farming.

The number of family dependents is also one of the factors that can influence a farm. The greater the number of family dependents, the more costs the farmer will bear to meet all the necessities of life for his family. The number of family dependents for respondents in Bangsala Village varies. Respondents who changed cocoa to corn were dominated by family dependents of 1-3 people, namely 39 people or $62 \%$ of the remaining respondents, with family dependents of $4-5$ people, namely 10 people or $38 \%$.

Land area greatly affects income, therefore the more land a farmer has, the greater the opportunity for the farmer to earn a higher income. This is in accordance with the opinion of Soekartawi (2002) which states that the area of agricultural land will affect the scale of business and this business scale will ultimately affect income. The results of the study indicate that the respondents have varied land areas. The number of respondents who had a moderate land area was 47 people with a percentage of $55.10 \%$ and respondents who had a large land area were 2 people with a percentage of $44.90 \%$. This is in accordance with the opinion expressed by Hernanto (1991), that there are three groups of farmers based on the area of land they use, namely narrow land area $(<0.5$ ha), medium land area (0.5-1ha), and large land area. ( $>1 \mathrm{ha})$.

\section{Transfer of Cocoa Commodities Into Corn}

Farmers in Bangsala Village started planting cocoa on their plantations in 1996 because at that time the price of cocoa was relatively high and farmers thought that cocoa plantations were very promising for their future lives. Plants that were previously planted by the community in Bangsala Village are generally those that have a high selling price and do not require difficult maintenance such as cacao plants. However, as time went on, the cocoa plantations that previously produced a lot of cocoa beans are now no longer producing much, the price of cocoa has decreased and because the cocoa is old so that it no longer produces much fruit, the income of farmers begins to decrease. This is what causes cocoa farmers in Bangsala Village, Porehu Sub District, North Kolaka District to shift some of their cocoa lands to become cornfields.

The process of transferring cocoa commodities to maize has occurred since 2015 until now in Bangsala Village, Porehu Sub District, North Kolaka District, but only a few farmers have done it. In 2015 , one by one, cocoa farmers had started to switch to corn, but the respondent farmers did not switch from cocoa to maize in all their cocoa fields, but farmers still left some of their cocoa fields for fear that one day the price of corn would drop. The decline in cocoa productivity causes the income 
received by farmers to below. In fact, in the field, production is always below the average of $279 \mathrm{Kg}$. The age of cocoa is one of the factors that has led to decreased cocoa productivity. The rejuvenation that has been done so far has not had a positive impact on increasing cocoa productivity. Unlike the case with corn production, whose production tends to increase and is quite stable with an average production of $2,361.2 \mathrm{Kg}$. Based on these problems, many farmers in Bangsala Village, Porehu Sub District began to transfer commodities in part of their land from cocoa to corn plants in 2015 until now. Therefore, the respondent still leaves his cocoa land for anticipation if the price of maize drops. Of course, this is not done directly by all farmers, but farmers convert their crops in a gradual manner. The following is a table of conditions for changes in the respondent's commodity:

Table 1. Changing conditions of farmer respondents in Bangsala Village Porehu Sub District, North Kolaka District

\begin{tabular}{cccc}
\hline No & $\begin{array}{c}\text { Change Gradually } \\
\text { (Years) }\end{array}$ & $\begin{array}{c}\text { Respondents } \\
\text { (Person) }\end{array}$ & $\begin{array}{c}\text { Percentage } \\
(\%)\end{array}$ \\
\hline 1 & 2015 & 6 & 6,12 \\
2 & 2016 & 8 & 4,8 \\
3 & 2017 & 10 & 14,28 \\
4 & 2018 & 10 & 26,54 \\
5 & 2019 & 15 & 44,89 \\
\hline & Total & 49 & 100 \\
\hline
\end{tabular}

Source: Primary Data, 2020

Based on the table of conditions for changes in respondent commodities, it can be seen that the most number of respondents who switched was in 2019 or with a percentage of $44.89 \%$ because in 2019 corn production tends to increase, prices remain stable and have never decreased from 2015 to the present because farmers saw firsthand the care of maize that did not require intensive care and did not require large costs so that in 2019 the number of farmers who switched to corn increased because it was considered more profitable. Then in 2015 as many as 6 people or with a percentage of $6.12 \%$, in 20165 people with a percentage of $4.8 \%$, in 2017 there were 10 people with a percentage of $14.28 \%$, in 2018 there were 10 people also with a percentage of $26.54 \%$.

\section{Factors Affecting Farmers to Transfer Commodities}

The reasons for farmers to change commodities from cocoa to corn include agronomic reasons in the form of difficult maintenance of cocoa plants, economic reasons in the form of low cocoa selling price and declining cocoa production, and social reasons such as seeing the success of friends, following friends and their own beliefs. Following are the reasons the respondents switched commodities as shown in Table 2

Table 2. Factors that influence farmers to switch commodities from cocoa to corn

\begin{tabular}{clcc}
\hline No & \multicolumn{1}{c}{ Farmers reason } & $\begin{array}{c}\text { Respondents } \\
\text { (Person) }\end{array}$ & $\begin{array}{c}\text { Percentage } \\
(\%)\end{array}$ \\
\hline 1 & Technical Aspects & & \\
& - Hard Cocoa Care & 45 & 91,83 \\
& - Pests and diseases Hard to control & 49 & 100 \\
& - The Age of Cocoa Plants is Old & 34 & 69,38 \\
\hline 2 & Economic Aspects & & \\
& - Low Selling Price & 49 & 100 \\
& - Lower Production & 49 & 100 \\
& - Low-Profit Rate & 49 & 100 \\
\hline 3 & Social Aspects & & \\
& - See Friends Success & 24 & 48,97 \\
& - Follow Friends & 13 & 26,53 \\
& - Own belief & 10 & 20,40 \\
\hline
\end{tabular}

Source: Primary Data, 2020

Based on Table 2, it can be seen that the main factor influencing farmers to transfer cocoa commodities to corn is the technical aspect, namely the low selling price of cocoa, lower cocoa production, and low-profit levels with a percentage of $100 \%$. According to Astuti et al., (2011), factors affecting land-use change are caused by economic aspects (price levels, harvest time, profit levels, 
production costs), environmental aspects (weather conditions, labor) and technical aspects (cultivation techniques, procurement of fertilizer). Furthermore, farmers transferring commodities is influenced by production costs and income (Saputra et al., 2012; Nurmedika, 2015; Fafa, 2016).

\section{Farmers' Income on Corn}

The amount of income of farmers in corn is very different from their income on cocoa. This high income has an impact on the income level of farmers in Bangsala Village, Porehu Sub District, North Kolaka District. The income they earn is sufficient to be used to meet the daily needs of people who do or divert part of their land to cultivate corn in Bangsala Village. The following is a table of farmers' income who converted part of their crop from cocoa to corn:

Table 3. Analysis of farmers' income switching from cocoa to corn

\begin{tabular}{clccc}
\hline No & \multicolumn{1}{c}{ Description } & Highest & Highest & Average \\
\hline 1 & Corn production Kg / season) & 3500 & 1500 & 2.361 .2 \\
2 & Corn Price (IDR) & 3.000 & 3.000 & - \\
3 & Variable Costs (IDR / Season) & 3.030 .000 & 1.025 .000 & 2.027 .500 \\
4 & Fixed Costs (IDR / Season) & 72.182 & 36.148 & 54.165 \\
5 & Total Cost (IDR / Season) & 3.102 .182 & 1.061 .148 & 2.455 .168 \\
6 & Income (IDR / Season) & 7.397 .818 & 3.438 .852 & $5.035 .184,2$ \\
\hline
\end{tabular}

Source: Primary Data, 2020

Based on Table 3 shows that the highest income obtained by farmers in Bangsala Village from their cornfields is IDR. 7,397,818 and the lowest income received by corn farmers was IDR. $3,438,852$ with an average change in income of IDR. 5,035,184.2 / Season. According to Dewi \& Sarjana (2015), there are factors that encourage the conversion of agricultural functions because the needs of farmer families who are urged by the need for business capital or other family needs make farmers have no choice but to replace their agricultural commodities.

\section{Income on Cocoa Farm}

According to Prayitno (1987), the size of farm income is determined by the area of arable land and the selling price. The income on the cocoa farm if it is not sufficient to meet the needs of the family. However, the income of farmers on cornfields is sufficient to meet their daily needs and help the family economy. The income of farmers in the cocoa field, if added with the income from the cornfield, can start repairing their houses and also buy various kinds of household equipment and can meet the daily needs of the people in Bangsala Village, Porehu Sub District, North Kolaka District.

Table 4. Analysis of farmers' income on cocoa land

\begin{tabular}{clccc}
\hline No & \multicolumn{1}{c}{ Description } & Highest & Highest & Average \\
\hline 1 & Corn production Kg / season) & 450 & 150 & 279 \\
2 & Corn Price (IDR) & 35.000 & 35.000 & 35.000 \\
4 & Variable Costs (IDR / Season) & 11.895 .644 & 3.529 .841 & 7.712 .743 \\
5 & Fixed Costs (IDR / Season) & 36.269 & 24.213 & 30.241 \\
6 & Total Cost (IDR / Season) & 11.931 .913 & 3.554 .054 & 12.441 .382 \\
7 & Income (IDR / Season) & 3.818 .087 & 1.695 .946 & 2.583 .621 \\
\hline
\end{tabular}

Source: Primary Data, 2020

Based on Table 4, it shows that the average income received by farmers on their cocoa land is IDR. 2,583,621 / Season. This total income is obtained from production multiplied by the price of cocoa $/ \mathrm{kg}$ and subtracted by the total cost obtained from variable costs and fixed costs on the cocoa farm, resulting in a small income. According to Dewi \& Sarjana (2015), there are factors that encourage the conversion of agricultural functions because the low incentives to do farming are caused by high production costs, while prices for agricultural products are relatively low and fluctuating.

\section{Analysis of Differences in Farmers' Income}

Based on the farm income data that has been described above in this study, it can be seen that the income of the respondent farmers in the cornfield is higher than the income in the cocoa field. The result of the t-test (Paired Samples Test) shows that the sig (2-tailed) value is $0.000<0.05$, it can 
be concluded that there is a significant difference between the income of the respondent farmers on maize land and on cocoa land, thus commodity transfer affects farmers' income. Aspects that cause differences in income are the amount of production, the price of corn production, production costs, and revenues.

\section{CONCLUSIONS AND SUGGESTIONS}

The conclusion that can be drawn from this research is that the factors that influence farmers to convert cocoa to corn are technical factors which include difficult cacao care, pests, and diseases that are difficult to control, and the age of the cocoa plant is old. Economic factors include low selling prices, lower production, and low-profit rates. Social factors include seeing the success of friends, following friends, and their own beliefs. The impact of the conversion of cocoa commodities to corn is seen in the increased income of farmers, farmers have additional income from their cocoa plantations, namely corn plants. It is clear here that the conversion of cocoa plant commodities to corn has a positive impact on the community in Bangsala Village, Porehu Sub District, North Kolaka District. The sig (2-tailed) value is $0.000<0.05$, that is, there is a significant difference between the income of the respondent farmers on the cornfield and on the cocoa field, thus the commodity transfer affects the farmer's income. The suggestion from this research is that factors that have a real effect on commodity transfer should be taken into consideration by farmers in carrying out the process of commodity transfer so that farmers can take a wise attitude.

\section{REFERENCES}

Astuti, U. P., Wibawa, W., \& Ishak, A. (2011). Faktor Yang Mempengaruhi Alih Fungsi Lahan Pangan Menjadi Kelapa Sawit di Bengkulu : Kasus Petani Di Desa Kungkai Baru. Seminar Nasional Budidaya Pertanian, 07 Juli 2011, Fakultas Pertanian Universitas Bengkulu.

BPS Kabupaten Kolaka Utara, (2019). Kolaka Utara dalam angka 2019. Badan Pusat Statistik Statistik Kolaka Utara. Lasusua

Dewi, I. A. D \& Sarjana, I. M. (2015). Faktor-Faktor Pendorong Alih fungsi Lahan Sawah Menjad Lahan Non-Pertanian (Kasus:Subak Kerdung Kecamatan Denpasar Selatan). Jurnal Manajemen Agribisnis Vol. 3, No. 2, Oktober 2015

Fafa, G. (2016). Persepsi Petani Terhadap Alih Fungsi Usaha Lahan Perkebunan Karet Ke Lahan Ubi Kayu di Desa Restu Rahayu Kecamatan Raman Utara Kabupaten Lampung Timur. Skripsi, STIPER Dharma Wacana Lampung.

Hernanto, F. (1991). Ilmu Usahatani. PT. Penebar Swadaya. Jakarta.

Nurmedika, Basir-Cylo, M., \& Damayanti, L. (2015). Analisis Faktor-Faktor Yang Mempengaruhi Pilihan Petani Melakukan Alih Usahatani. di Kecamatan Rio Pakava Kabupaten Donggala. Jurnal Agroland. 22(1): 9-20

Nurmedika., Basir M., \& Damayanti, L. (2015). Analisis Faktor-Faktor Yang Mempengaruhi Pilihan Petani Melakukan Alih Usahatani. di Kecamatan Rio Pakava Kabupaten Donggala. Jurnal Agroland. 22(1): 9-20

Prayitno, H., \& Arsyad, L., (1987). Petani dan Kemiskinan, Edisi Pertama, BPFE, Yokyakarta.

Soehardjo \& Patong, D. (1999). Sendi-Sendi Proyek IImu Usahatani. Departemen IImu-IImu Sosial. Institute Pentanian Bogor. Bogor

Soekartawi, (2002). Analisis Usahatani. UI Press. Jakarta

Suputra, D., Ambarawati, I., \& Tenaya, I. (2012). Faktor-Faktor yang Mempengaruhi Alih Fungsi Lahan Studi Kasus di Subak Daksina, Desa Tibubeneng, Kecamatan Kuta Utara, Kabupaten Badung. Jurnal Agribisnis Dan Agrowisata (Journal of Agribusiness and Agritourism), . Retrieved from https://ojs.unud.ac.id/index.php/JAA/article/view/1129

Syahrial, M. (2019). Panduan Lengkap Dan Praktis Budidaya Jagung Yang Paling Menguntungkan. Garuda Pustaka. Jakarta Timur 